\title{
Prioritizing Substances of Genotoxic Concern for In-Depth Safety Evaluation Using Non-Animal Approaches: The Example of Food Contact Materials
}

\author{
Melissa Van Bossuyt 1,2, Els Van Hoeck ${ }^{1}$, Tamara Vanhaecke ${ }^{2}$, Vera Rogiers ${ }^{2 \#}$ and Birgit Mertens ${ }^{1 \#}$ \\ ${ }^{1}$ Scientific Direction Chemical and Physical Health Risks, Sciensano, Brussels, Belgium; ${ }^{2}$ Department of In Vitro Toxicology and Dermato-Cosmetology, \\ Vrije Universiteit Brussel, Brussels, Belgium
}

\begin{abstract}
Due to the exponentially growing number of substances requiring safety evaluation, efficient prioritization strategies are needed to identify those of highest concern. To limit unnecessary animal testing, such strategies should respect the $3 R$ principles (Replacement, Reduction, Refinement). In the present study, a strategy based on non-animal approaches was developed to prioritize non-evaluated printed paper and board food contact material (FCM) substances for further in-depth safety evaluation. Within the strategy, focus was placed on genotoxicity, a key toxicological endpoint when evaluating safety. By combining in silico predictions with existing in vitro and in vivo genotoxicity data from publicly available literature sources and results from in vitro gene mutation experiments, the 106 study substances could all be assigned to one of the four priority classes (ranging from low to very high concern). Importantly, 19 substances were considered of very high concern due to in vivo genotoxicity. Five of these are furthermore listed as substances of very high concern (SVHC) by the European Chemicals Agency (ECHA), in addition to demonstrating physicochemical properties linked to a high migration potential as well as oral bioavailability and being used in primary food packaging materials. The current animal-free strategy proved useful for the priority ranking of printed paper and board FCM substances, but it may also be considered to prioritize other substances of emerging concern.
\end{abstract}

\section{Introduction}

Over the last decades, the number of substances suspected of posing a risk to human health and/or the environment has significantly increased (Sauvé and Desrosiers, 2014; Alphenaar and van Houten, 2016). Substances of emerging concern can be naturally-occurring or manmade, and they may exist already for quite some time prior to raising concerns. Typically, little is known about their occurrence in the environment, the toxic effects they may cause (Sauvé and Desrosiers, 2014), and the extent to which humans are exposed. The large amount of substances concerned presents a challenge for regulatory authorities who are responsible for the implementation of adequate safety measures to limit chemical threats to human health and the environment. Strategies to quickly identify the substances of highest concern that are also applicable to different types of substances, are therefore of high interest.

One important group of substances that may pose a risk to human health are those used in - and potentially migrating from
- food contact materials (FCM). Initially not considered as a major source of food contamination, FCM have gained increasing attention over the last years (Grob et al., 2006; Borchers et al., 2010; Muncke, 2011; Claudio, 2012; Geueke et al., 2014; EU, 2016). Indeed, although concentrations of FCM-related contaminants in food are generally rather low, exposure can occur in the entire consumer population and for long periods of time, potentially a whole lifetime (Muncke et al., 2014).

For plastic FCM, a European Union list of authorized substances has been put in place which is regularly updated (EU, 2011). Non-plastic FCM are not yet subject to specific harmonized legislation, although they must adhere to the general EU Framework Regulation, which states that all FCM must be safe (EU, 2004). At the Member State level, legislation for non-plastics is usually limited and detailed requirements are rarely set. Hence, it is not surprising that current migration issues mainly arise from non-plastic FCM rather than from their plastic counterparts (EFSA, 2012). Printed paper and board FCM constitute a major group of non-plastics and are recognized as an im-

\footnotetext{
\# contributed equally

Received October 1, 2018; Accepted November 22, 2018; Epub November 28, 2018; () The Authors, 2018
}

ALTEX 36(2), 215-230. doi:10.14573/altex.1810011
This is an Open Access article distributed under the terms of the Creative Commons Attribution 4.0 International license (http://creativecommons.org/licenses/by/4.0/), which permits unrestricted use, distribution and reproduction in any medium, provided the original work is appropriately cited. 
portant source of food contaminants (Bengtström et al., 2016; Rosenmai et al., 2017). We recently reported that more than 6000 substances can be used in the manufacture of printed paper and board FCM, of which $77 \%$ have not been officially evaluated for their safe use in FCM. Furthermore, based on their physicochemical characteristics, the majority of these non-evaluated substances is expected to migrate from the FCM and become bioavailable after intake of the contaminated food (Van Bossuyt et al., 2016). Since elaborate safety testing on these thousands of printed paper and board FCM substances is not feasible in the short term, they constitute an interesting group for the development of a prioritization strategy for subsequent in-depth safety evaluation.

As a first step in such a strategy, in silico tools may be of particular interest. In a previous study, we have shown that 106 printed paper and board substances were predicted to induce gene mutations by up to 4 (quantitative) structure-activity relationship ((Q)SAR) tools and, hence, they are of high priority for further investigation (Van Bossuyt et al., 2017). Together with structural and numerical chromosome aberrations, gene mutations are the key endpoints that need to be addressed when investigating the genotoxic potential of a compound. However, as in silico models are most advanced to predict the compounds' potential to induce gene mutations, emphasis was put on this endpoint.

The present study aims to refine this in silico tools-based prioritization strategy by collecting experimental genotoxicity data in compliance with the $3 \mathrm{R}$ principles (i.e., Replacement, Reduction, and Refinement) in order to limit the use of experimental animals (Russell and Burch, 1959). For example, the use of existing data can make new testing redundant. Furthermore, if no (reliable) data are available, non-animal methods (e.g., in vitro applications) should first be considered to further reduce the need for in vivo experiments (OECD, 2000; EU, 2010).

To collect existing in vitro and in vivo genotoxicity data, a literature survey was performed on the 106 printed paper and board FCM substances prioritized earlier (Van Bossuyt et al., 2017). Collection of data was not limited to results of gene mutation tests, but also included results from tests investigating structural and numerical chromosome aberrations. Data were collected starting from previous evaluations of the substances carried out by European authorities in another context than their use in FCM. When an official evaluation in a non-FCM context had not been performed or no clear conclusion on in vivo genotoxicity was formulated, two publicly available inventories, i.e., (i) the Genotoxicity and Carcinogenicity Consolidated Database of Ames Positive Chemicals of the Euro- pean Union Reference Laboratory for alternatives to animal testing (EURL ECVAM database) (EU, 2017b) and (ii) the European Chemicals Agency (ECHA) database ${ }^{1}$ were consulted. Furthermore, it was verified whether the substance had been classified for mutagenicity under the Classification, Labelling and Packaging (CLP) regulation (EU, 2008). In the second part of the study, the substances without (adequate) literature data were tested in vitro in a bacterial reverse gene mutation test (i.e., Ames test). Additionally, this gene mutation test was also performed on substances for which negative, yet unofficial, experimental results have been reported in the open literature, in order to assess whether these results can be reproduced. Based on the collected experimental data, printed paper and board FCM substances were further ranked according to the need for an in-depth evaluation of their toxicity, migration potential into food, and actual use in FCM.

\section{Materials and methods}

\subsection{Study substances}

One hundred and six non-evaluated printed paper and board FCM substances that were assigned high priority for further investigation of their genotoxic potential based on their positive results in a battery of 4 in silico tools (Van Bossuyt et al., 2017) were selected for the present study.

\subsection{Literature consultation}

Different information sources were consulted to verify whether in vitro and/or in vivo genotoxicity data on the 106 selected substances were already available.

\section{Evaluations by EU authorities and Member States \\ in a non-FCM context}

Genotoxicity data were collected from Opinion documents published by the European Food Safety Authority (EFSA) (consultation of the Open Food Tox database through the OECD eChemPortal (OECD, 2017)), the Scientific Committee on Consumer Safety (SCCS), and the prior Scientific Committee on Consumer Products (SCCP). Furthermore, genotoxicity data from official evaluations performed by Member States in the context of the Biocidal Products Regulation (EU) 528/2012 (EU, 2012), the Registration, Evaluation, Authorisation and Restriction of Chemicals (REACH) regulation (EU, 2006), and the previous Council Regulation (EEC) 793/931 on the evaluation and control of the risks of existing substances (EU, 1993) were also considered (consultation through the ECHA website ${ }^{1}$ ).

\footnotetext{
1 European Chemicals Agency (ECHA) database. https://www.echa.europa.eu
}

CLP, Classification, Labelling and Packaging; CMR, carcinogenic, mutagenic or toxic to reproduction; CoRAP, Community Rolling Action Plan; DMSO, dimethyl sulfoxide; ECHA, European Chemicals Agency; EFSA, European Food Safety Authority; EURL ECVAM, European Union Reference Laboratory for alternatives to animal testing; FACET, Flavourings, Additives, and food Contact materials Exposure Tool; FCM, food contact materials; FMN, flavin mononucleotide; G6P, glucose 6-phosphate; IARC, International Agency for Research on Cancer; NADH, nicotinamide adenine dinucleotide; NADPH, nicotinamide adenine dinucleotide phosphate; OECD, Organisation for Economic Co-operation and Development; (Q)SAR, (quantitative) structure-activity relationship; REACH, Registration, Evaluation, Authorisation, and Restriction of Chemicals; SCCP, Scientific Committee on Consumer Products; SCCS, Scientific Committee on Consumer Safety; SVHC, Substances of Very High Concern 


\section{The EURL ECVAM and ECHA databases}

In case an official European evaluation was lacking or insufficient to assess the in vivo genotoxic potential of a substance, two public EU substance databases were consulted. First, inclusion of the substance in the EURL ECVAM database (EU, 2017b) was verified. This database contains in vitro and in vivo genotoxicity and carcinogenicity data on 726 substances that induce gene mutations in the Ames test. It was initially constructed to evaluate the predictivity of the Ames test - alone or in combination with in vitro mammalian cell assays - for in vivo genotoxicity and carcinogenicity (Kirkland et al., 2014). However, the EURL ECVAM database can as such also serve as a source of genotoxicity data.

Since the EURL ECVAM database only includes substances that are positive in the Ames test, the ECHA database ${ }^{1}$ was used as a second information source. Through its website, the ECHA makes available chemical substance data submitted under the framework of the REACH regulation (EU, 2006). For registered substances, toxicological information is available, although the type and the amount of information depends on the tonnage band and envisaged use of the substance. When manufactured or imported in quantities exceeding 1 ton per year, genotoxicity data - at least on gene mutation potential - are required, except for some substances registered as intermediates. The REACH registration status of the study substances was checked based on their CAS number and data were collected following the approach described by Mertens and colleagues (2016). All available in vitro and in vivo genotoxicity data of studies with a Klimisch score of 1 (reliable without restrictions) or 2 (reliable with restrictions) were retained (Klimisch et al., 1997).

Based on the genotoxicity data retrieved from the EURL ECVAM and ECHA databases, a final call (positive, negative, or inconclusive) was made per substance for each in vitro and in vivo genotoxicity endpoint. In case a positive result was reported in terms of gene mutations or structural or numerical chromosome aberrations, the substance was considered genotoxic. If results of both gene mutation and chromosome aberration tests were negative or in vitro positive results were not confirmed in an adequate in vivo follow-up test, the substance was considered non-genotoxic. No overall conclusion was formulated whenever test data were incomplete, inadequate, or ambiguous.

Harmonized classification according to the CLP regulation For all substances, it was investigated whether a harmonized classification for mutagenicity has been established under the CLP regulation (EU, 2008). When assigned to one of the dif- ferent mutagenicity categories described in this regulation (Tab. 1), a substance can be considered mutagenic (i.e., inducing gene mutations and/or chromosome aberrations) based on the available evidence. It is generally recommended that for non-harmonized FCM such as printed paper and board, substances classified as carcinogenic, mutagenic, or toxic to reproduction (CMR) should not be used (European Parliamentary Research Service, 2016).

\section{Training set substances}

Substances for which no public literature data could be retrieved from the selected information sources, but that are included in the training set of one or more of the in silico gene mutation prediction models as indicated by Van Bossuyt et al. (2017), were considered in vitro genotoxic. Indeed, fifty-three substances were previously found in the training set of at least one of the in silico models, indicating that positive experimental gene mutation test data have already been reported (Van Bossuyt et al., 2017). However, these data are not necessarily publicly available and could therefore not be verified.

\subsection{Substance categorization based on collected literature data}

The data collected from the literature sources described in section 2.2 were combined to assign each of the 106 substances to one of the following categories:

- Category 1: Substances for which there is evidence that they are genotoxic in vivo, including substances classified as mutagen category $1 \mathrm{~A}, 1 \mathrm{~B}$, or 2 according to the CLP regulation.

- Category 2: Substances for which there is evidence that they are genotoxic in vitro but for which in vivo follow-up data are needed.

- Category 3: Substances for which (more) in vitro genotoxicity data are needed.

- Category 4: Substances for which the available data support the absence of genotoxicity in vitro.

- Category 5: Substances for which the available data support the absence of genotoxicity in vivo.

Substances assigned to category 3 were further divided into two subcategories depending on the number of genotoxic endpoints for which in vitro genotoxicity data are needed. More specifically, substances lacking data from both gene and chromosome mutation tests were prioritized over substances for which (negative) data were available for one of these endpoints.

- Category 3A: Substances for which in vitro data on both gene and chromosome mutation potential are needed.

Tab. 1: Categorization of mutagens according to the CLP regulation

\begin{tabular}{|l|l|}
\hline Category & Description \\
\hline $1 \mathrm{~A}$ & Substance known to induce heritable mutations in the germ cells of humans \\
\hline $1 \mathrm{~B}$ & Substance to be regarded as if it induces heritable mutations in the germ cells of humans \\
\hline 2 & $\begin{array}{l}\text { Substance which causes concern for humans owing to the possibility that it may induce heritable mutations in } \\
\text { the germ cells of humans }\end{array}$ \\
\hline
\end{tabular}


- Category 3B: Substances for which the available in vitro data support the absence of gene mutation potential but for which data on chromosome aberration potential are needed ${ }^{2}$.

\subsection{Substances selected for in vitro gene mutation study}

A bacterial reverse gene mutation test was performed on the substances of category $3 \mathrm{~A}$. Furthermore, the substances of categories $3 \mathrm{~B}$ and 4 were also included in the in vitro part of this study, as the negative gene mutation test results available for these substances have not been subjected to an independent, official evaluation. Importantly, only those selected substances that are (commercially) available could actually be tested in vitro (Tab. 4, 5).

\subsection{In vitro bacterial reverse gene mutation test (Ames test)}

The substances selected from categories 3A, 3B, and 4 were evaluated by means of a bacterial reverse gene mutation test (further referred to as "Ames test") according to OECD test guideline 471 (OECD, 1997), with specific test conditions based on the paper by Mortelmans and Zeiger (2000). Normally, the test uses five different bacterial strains. However, since a substance is considered positive if it induces a positive result in at least one tester strain, an initial Ames test was done in Salmonella typhimurium TA100 (detection of base pair substitutions (Barnes et al., 1982)) with and without an external metabolic activation system. Only in case a negative result was obtained, the substance was also tested in a second bacterial strain, i.e., Salmonella typhimurium TA98 (detection of frameshifts (Isono and Yourno, 1974)). Substances negative with and without metabolization in both TA100 and TA98 should normally be further tested in the remaining tester strains of the OECD standard set. However, this was outside the scope of the current prioritization strategy, as the two selected bacterial strains already allow identification of up to $90 \%$ of mutagens (Zeiger et al., 1985).

Ames bacteria (Moltox, Boone, USA) were grown overnight and $100 \mu \mathrm{l}$ were mixed with $100 \mu \mathrm{l}$ of the test solution, $500 \mu \mathrm{l}$

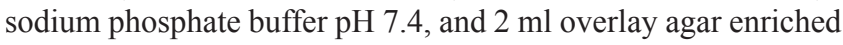
with a histidine-biotine solution. To test the substance in its metabolized form, the buffer was replaced by a 5\% S9 metabolization mix (prepared from lyophilized rat liver S9 mixed with nicotinamide adenine dinucleotide phosphate (NADPH) regenerating system - both from Moltox). The resulting mixture was poured onto a minimal glucose agar plate (E\&O Laboratories Ltd., Bonnybridge, United Kingdom) and incubated for 48 hours at $37^{\circ} \mathrm{C}$ (Binder, Tuttlingen, Germany). Triplicate plates were poured for each test condition.

In accordance with the principles of OECD test guideline 471, the substances with a (di)azo structure were tested using a modified protocol (Prival and Mitchell, 1982), for which materials were obtained from Trinova Biochem (Gießen, Germany). Pre-incubation was performed using an incubating mini shaker
(VWR, Radnor, USA) set to $30^{\circ} \mathrm{C}$ and 240 rotations per minute (rpm). In their publication, Prival and Mitchell used strain TA98 and therefore this strain was also selected for the current study. Normally, testing in the other strains may be considered when a substance is negative in strain TA98; however, this was outside the scope of the current prioritization strategy.

All substances were tested in at least five concentrations as prescribed by OECD test guideline 471 (OECD, 1997). Ultrapure sterile water was the solvent of choice, whereas water-insoluble substances were dissolved in dimethyl sulfoxide (DMSO). Positive, negative, and solvent control plates were prepared in parallel with the test substance plates. For the tests without $\mathrm{S} 9$ metabolization mix, sodium azide ( $2 \mu \mathrm{g} / \mathrm{plate})$ and 4-nitroquinoline-n-oxide $(0.2 \mu \mathrm{g} /$ plate $)$ were used as a positive control for strain TA100 and TA98, respectively. 2-Aminoanthracene $(1 \mu \mathrm{g} /$ plate $)$ was used for the tests with metabolic activation. Congo red $(100 \mu \mathrm{g} /$ plate $)$ was selected as a positive control for the modified tests on (di)azo compounds, based on the report by Prival et al. (1984) and the results of a preliminary Ames test performed by the host lab to investigate the suitability of Congo red for this purpose. All positive control substances and DMSO were purchased from Sigma-Aldrich (Saint-Louis, USA).

After incubation, the plates were inspected for cytotoxicity and precipitation by examining the background lawn using a light microscope (Zeiss, Oberkochen, Germany) at 40x total magnification. Although slight cytotoxicity or precipitation may not invalidate the experiment, they may interfere with colony counting and affect the interpretation of the results (Mortelmans and Zeiger, 2000).

All plates were subsequently scored using a manual colony counter (Sigma-Aldrich, Saint-Louis, USA). Individual plate counts were recorded and the mean number of revertant colonies per plate as well as the standard deviation was calculated. Specific criteria to consider a substance as positive included:

1. A concentration-related increase in the number of revertant colonies per plate in at least one strain with or without metabolic activation system;

2. For at least one test concentration, the number of revertant colonies $>2 \mathrm{x}$ the number of revertant colonies in the solvent control.

\subsection{Substance prioritization for in-depth safety evaluation based on collected genotoxicity data}

All genotoxicity data collected from the literature consultation and the Ames test were finally combined to assign each of the 106 substances to one of the following priority classes:

- Very high priority: substances for which there is (official) evidence that they are genotoxic in vivo and/or that are subject to harmonized CLP classification for mutagenicity.

- High priority: substances for which there is evidence that they are genotoxic in vitro but for which in vivo follow-up data are needed.

2 The opposite situation, i.e., substances with available in vitro data supporting the absence of chromosome damaging potential but for which data on gene mutation potential are needed, did not occur in the present study. 
- Medium priority: substances for which in vitro genotoxicity data are insufficient or for which an official evaluation of the reported negative results is needed.

- Low priority: substances considered non-genotoxic in vivo based on an official evaluation performed by an EU authority or Member State.

\section{Results and discussion}

\subsection{Genotoxicity data collected from the scientific literature}

The literature consultation demonstrated that only for 11 out of the 106 study substances, an official evaluation of their genotoxic potential has been performed in a non-FCM context in Europe (Tab. 2). Among these substances, five were confirmed to be in vivo genotoxicants, whereas three were considered not having the property to induce genotoxic effects in vivo. The available genotoxicity data of the remaining three substances were insufficient to draw a conclusion on in vivo genotoxicity. For these three substances, and the remaining 95 substances for which no previous EU evaluation was found, the EURL ECVAM and ECHA databases were consulted to search for additional genotoxicity data (Fig. 1).

Genotoxicity data could be retrieved from the EURL ECVAM and/or ECHA database for a total of 49 substances (Tab. 3). More specifically, 20 substances were included in the EURL
ECVAM database and up to 45 substances had been registered under the REACH framework. Sixteen substances were thus present in both databases. However, no experimental genotoxicity data could be obtained from the ECHA database for three of these, since they were registered for intermediate use only (CAS number 75-55-8 and 96-23-1) or the information was limited to read-across data (CAS number 111-44-4). For the 13 substances with genotoxicity data available in both databases, the outcomes for the different genotoxicity endpoints were largely concordant, with the exception of 3 substances (CAS number 78-87-5, 10707-3, and 556-52-5) for which a negative result was reported by REACH registrants whereas a positive result was reported in the EURL ECVAM database. Furthermore, there was 1 substance (CAS number 100-44-7) with ambiguous in vivo micronucleus test results according to ECHA, although it was considered negative for the same test in the EURL ECVAM database. For these 4 compounds, a worst-case scenario was applied by selecting the positive (or ambiguous) result as the overall result for the respective endpoint. A final call in terms of in vivo genotoxicity was made for each substance listed in the EURL ECVAM and/ or ECHA database, resulting in 10 substances identified as in vivo genotoxins, while 4 others were considered non-genotoxic in vivo. For the majority of 35 substances, however, the available genotoxicity data were insufficient due to various reasons. Lack of in vivo follow-up testing of a positive in vitro result was the predominant reason (19 substances), although incomplete coverage of both gene mutation and chromosome aberration

Tab. 2: Final call for in vivo genotoxicity of the 11 substances previously evaluated in Europe in a non-FCM context Results are expressed as positive (+), negative (-) or equivocal/insufficient $( \pm)$.

\begin{tabular}{|c|c|c|c|}
\hline CAS number & Chemical name & $\begin{array}{l}\text { EU authority/ } \\
\text { Member State }\end{array}$ & In vivo genotoxicity \\
\hline $74-87-3$ & Chloromethane & Italya & + \\
\hline $77-78-1$ & Dimethyl sulphate & The Netherlands ${ }^{a}$ & + \\
\hline $101-77-9$ & 4,4'-Methylenedianiline & Germanya & + \\
\hline $2386-87-0$ & $\begin{array}{l}\text { 7-Oxabicyclo[4.1.0]hept-3-ylmethyl 7-oxabicyclo [4.1.0]heptane-3- } \\
\text { carboxylate }\end{array}$ & Ireland $^{\mathrm{a}}$ & + \\
\hline 2451-62-9 & 1,3,5-Tris(oxiranylmethyl)-1,3,5-triazine-2,4,6(1H,3H,5H)-trione & Poland ${ }^{\mathrm{a}}$ & + \\
\hline $85-83-6$ & 1-(2-Methyl-4-(2-methylphenylazo)phenylazo)-2-naphthol & EFSA & \pm \\
\hline $85-86-9$ & 1-(4-(Phenylazo)phenylazo)-2-naphthol & $\begin{array}{l}\text { EFSA } \\
\text { SCCP }\end{array}$ & $\begin{array}{l} \pm \\
\pm\end{array}$ \\
\hline $107-02-8$ & Acrylaldehyde & $\begin{array}{l}\text { The Netherlands }{ }^{a} \\
\text { United Kingdom } b\end{array}$ & \pm \\
\hline $106-50-3$ & $\mathrm{p}$-Phenylenediamine & sccs & - \\
\hline $128-95-0$ & 1,4-Diaminoanthraquinone & SCCS & - \\
\hline $39817-09-9$ & 2,2'-[Methylenebis(phenylene oxymethylene)]bisoxirane & EFSA & - \\
\hline
\end{tabular}

EFSA, European Food Safety Authority; SCCP, Scientific Committee on Consumer Products; SCCS, Scientific Committee on Consumer Safety. ${ }^{\text {a }}$ The evaluation was performed in the context of the REACH Regulation or the previous Council Regulation on the evaluation and control of the risks of existing substances. ${ }^{b}$ The evaluation was performed in the context of the Biocidal Products Regulation. 
Tab. 3: Overview of in vitro and in vivo genotoxicity data for the 49 substances for which no previous European evaluation is available but that are present in the ECHA and/or EURL ECVAM database

For each endpoint, the results are expressed as positive (+), negative (-), equivocal/insufficient ( \pm ) or not available (NA).

\begin{tabular}{|c|c|c|c|c|c|c|c|c|c|c|}
\hline \multirow[t]{2}{*}{$\begin{array}{l}\text { CAS } \\
\text { number }\end{array}$} & \multirow{2}{*}{$\begin{array}{l}\text { Included } \\
\text { in EURL } \\
\text { ECVAM } \\
\text { database }\end{array}$} & \multicolumn{2}{|c|}{$\begin{array}{l}\text { Included in ECHA } \\
\text { database }\end{array}$} & \multicolumn{3}{|c|}{ In vitro genotoxicity } & \multicolumn{3}{|c|}{ In vivo genotoxicity } & \multirow[t]{2}{*}{ Final call } \\
\hline & & Registered & Evaluated & $\begin{array}{l}\text { Gene } \\
\text { muta- } \\
\text { tions }\end{array}$ & $\begin{array}{l}\text { Chromo- } \\
\text { some } \\
\text { aberra- } \\
\text { tions }\end{array}$ & $\begin{array}{l}\text { Non- } \\
\text { specific } \\
\text { geno- } \\
\text { toxicity }\end{array}$ & $\begin{array}{l}\text { Gene } \\
\text { muta- } \\
\text { tions }\end{array}$ & $\begin{array}{l}\text { Chromo- } \\
\text { some } \\
\text { aberra- } \\
\text { tions }\end{array}$ & $\begin{array}{l}\text { Non- } \\
\text { specific } \\
\text { geno- } \\
\text { toxicity }\end{array}$ & \\
\hline $57-14-7$ & Yes & Yes & No & + & + & NA & NA & + & NA & + \\
\hline $75-55-8$ & Yes & Yes $^{a}$ & No & + & NA & NA & NA & + & NA & + \\
\hline $101-80-4$ & Yes & Yes & No & + & + & + & NA & + & - & + \\
\hline $106-92-3$ & Yes & Yes & No & + & + & + & \pm & + & NA & + \\
\hline $107-07-3$ & Yes & Yes & No & + & + & + & \pm & + & - & + \\
\hline $302-01-2$ & Yes & Yes & No & + & + & NA & \pm & + & + & + \\
\hline $556-52-5$ & Yes & Yes & No & + & + & + & \pm & + & + & + \\
\hline $2426-08-6$ & Yes & No & No & + & NA & NA & NA & + & NA & + \\
\hline $2530-83-8$ & No & Yes & No & + & NA & + & NA & + & - & + \\
\hline $4170-30-3$ & No & Yes $^{b}$ & No & + & + & + & \pm & + & + & + \\
\hline $75-00-3$ & Yes & Yes & No & + & NA & NA & NA & - & - & \pm \\
\hline $78-87-5$ & Yes & Yes & No & + & + & NA & NA & - & NA & \pm \\
\hline $96-23-1$ & Yes & Yes $^{a}$ & No & + & NA & NA & NA & NA & NA & \pm \\
\hline $98-88-4$ & No & Yes & No & - & NA & NA & NA & NA & NA & \pm \\
\hline $100-44-7$ & Yes & Yes & No & + & + & NA & \pm & \pm & NA & \pm \\
\hline $106-88-7$ & Yes & Yes & No & + & + & NA & NA & - & NA & \pm \\
\hline $107-02-8$ & Yes & Yes & No & + & - & \pm & NA & - & NA & \pm \\
\hline $107-05-1$ & Yes & Yes & No & + & + & NA & \pm & - & NA & \pm \\
\hline $111-44-4$ & Yes & $Y^{c}{ }^{c}$ & No & + & NA & NA & NA & NA & NA & \pm \\
\hline $111-64-8$ & No & Yes & No & - & NA & NA & NA & NA & NA & \pm \\
\hline $122-60-1$ & Yes & Yes $^{b}$ & No & + & \pm & + & NA & - & NA & \pm \\
\hline $123-73-9$ & Yes & No & No & + & + & NA & NA & - & NA & \pm \\
\hline $286-20-4$ & No & Yes & No & + & NA & + & NA & - & NA & \pm \\
\hline $558-30-5$ & No & Yes & No & + & + & NA & NA & NA & NA & \pm \\
\hline $624-65-7$ & No & Yes & No & + & NA & NA & NA & - & NA & \pm \\
\hline $1719-57-9$ & No & Yes & No & - & NA & NA & NA & NA & NA & \pm \\
\hline $2210-79-9$ & No & Yes & $\mathrm{O}(\mathrm{DK})$ & + & NA & + & \pm & - & NA & \pm \\
\hline $2478-20-8$ & No & Yes & No & + & NA & NA & NA & NA & NA & \pm \\
\hline 2602-34-8 & No & Yes & No & + & NA & NA & NA & NA & - & \pm \\
\hline $2897-60-1$ & No & Yes & No & + & + & NA & NA & - & NA & \pm \\
\hline $3049-71-6$ & No & Yes & No & + & NA & NA & NA & NA & NA & \pm \\
\hline $3101-60-8$ & No & Yes & No & + & + & + & NA & NA & NA & \pm \\
\hline $3252-43-5$ & Yes & No & No & + & NA & NA & NA & - & NA & \pm \\
\hline $3266-23-7$ & No & Yes & No & \pm & NA & NA & NA & NA & NA & \pm \\
\hline $5026-74-4$ & No & Yes & $\mathrm{O}(\mathrm{DK})$ & + & + & NA & NA & NA & NA & \pm \\
\hline
\end{tabular}




\begin{tabular}{|c|c|c|c|c|c|c|c|c|c|c|}
\hline \multirow[t]{2}{*}{$\begin{array}{l}\text { CAS } \\
\text { number }\end{array}$} & \multirow{2}{*}{$\begin{array}{l}\text { Included } \\
\text { in EURL } \\
\text { ECVAM } \\
\text { database }\end{array}$} & \multicolumn{2}{|c|}{$\begin{array}{l}\text { Included in ECHA } \\
\text { database }\end{array}$} & \multicolumn{3}{|c|}{ In vitro genotoxicity } & \multicolumn{3}{|c|}{ In vivo genotoxicity } & \multirow[t]{2}{*}{ Final call } \\
\hline & & Registered & Evaluated & $\begin{array}{l}\text { Gene } \\
\text { muta- } \\
\text { tions }\end{array}$ & $\begin{array}{l}\text { Chromo- } \\
\text { some } \\
\text { aberra- } \\
\text { tions }\end{array}$ & $\begin{array}{l}\text { Non- } \\
\text { specific } \\
\text { geno- } \\
\text { toxicity }\end{array}$ & $\begin{array}{l}\text { Gene } \\
\text { muta- } \\
\text { tions }\end{array}$ & $\begin{array}{l}\text { Chromo- } \\
\text { some } \\
\text { aberra- } \\
\text { tions }\end{array}$ & $\begin{array}{l}\text { Non- } \\
\text { specific } \\
\text { geno- } \\
\text { toxicity }\end{array}$ & \\
\hline $6471-49-4$ & Yes & No & No & + & - & NA & NA & NA & NA & \pm \\
\hline $6471-50-7$ & No & Yes & No & - & NA & NA & NA & NA & NA & \pm \\
\hline $12236-64-5$ & No & Yes & No & - & NA & NA & NA & NA & NA & \pm \\
\hline $36968-27-1$ & No & Yes & No & - & NA & NA & NA & NA & NA & \pm \\
\hline $51920-12-8$ & No & Yes & No & - & NA & NA & NA & NA & NA & \pm \\
\hline $59487-23-9$ & No & Yes & No & - & NA & NA & NA & NA & NA & \pm \\
\hline $61847-48-1$ & No & Yes & No & - & NA & NA & NA & NA & NA & \pm \\
\hline 67990-05-0 & No & Yes & No & - & NA & NA & NA & NA & NA & \pm \\
\hline $68227-78-1$ & No & Yes & No & \pm & - & NA & NA & NA & - & \pm \\
\hline $68516-75-6$ & No & Yes & No & - & NA & NA & NA & NA & NA & \pm \\
\hline $4378-61-4$ & No & Yes & No & - & - & NA & NA & NA & NA & - \\
\hline $6448-95-9$ & No & Yes & No & - & - & NA & NA & NA & NA & - \\
\hline $12225-06-8$ & No & Yes & No & - & - & NA & NA & NA & NA & - \\
\hline $74336-59-7$ & No & Yes & No & - & - & NA & NA & NA & NA & - \\
\hline
\end{tabular}

DK, Denmark; O, evaluation by a European Member State is on-going or planned. ${ }^{\text {a }}$ The substance is registered for intermediate use only and genotoxicity data are not available. ${ }^{b}$ The substance is registered for intermediate use only and genotoxicity data are available. ${ }^{c}$ The substance is registered, but genotoxicity data are based on read-across studies instead of experimental testing.

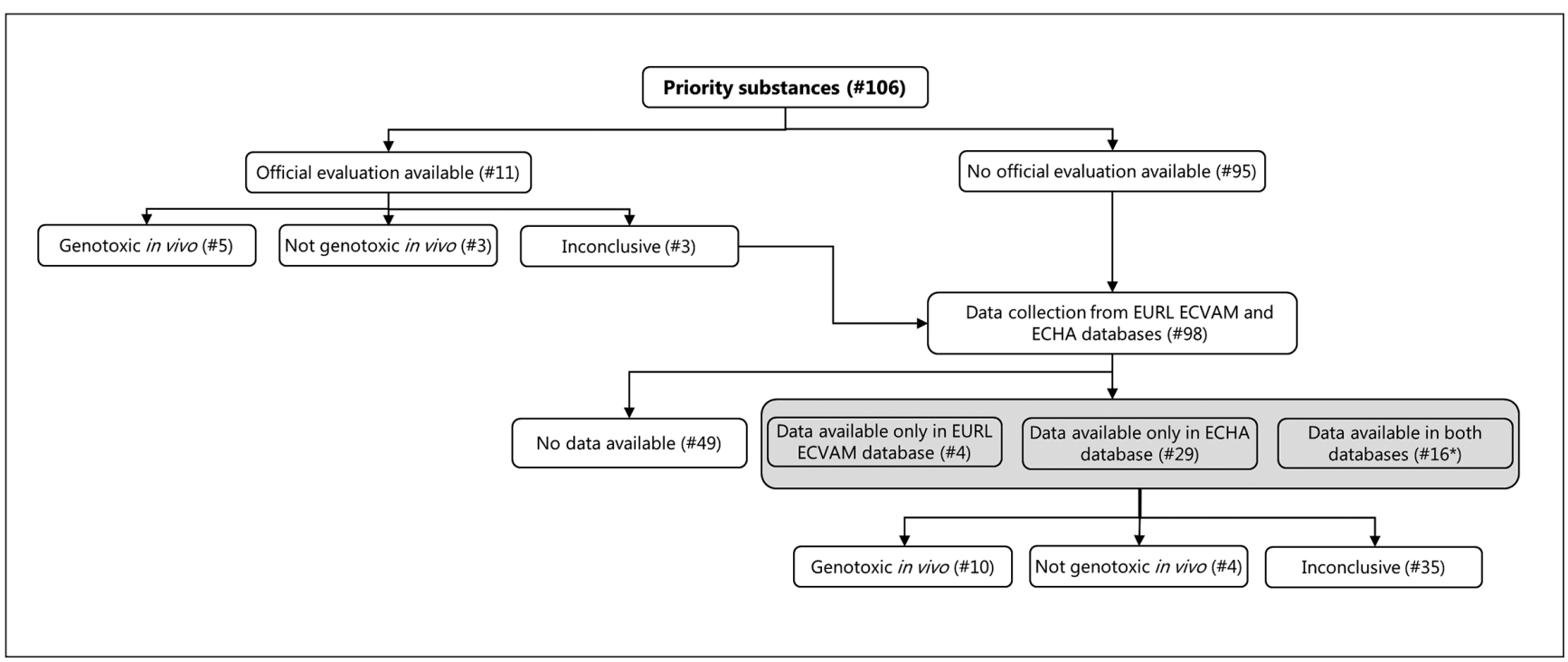

Fig. 1: Summary of literature data collection steps and outcomes

* Three of these substances were included in the ECHA database but no experimental genotoxicity data were available as they were registered for intermediate use only. 
endpoints (11 substances) and ambiguous results (5 substances) were also common. Through the Community Rolling Action Plan (CoRAP) incentive, the substance 2,3-epoxypropyl o-tolyl ether (CAS number 2210-79-9) that produced ambiguous results has been selected for an official evaluation to be performed by Denmark. However, the Danish authorities have requested more information in order to evaluate the potential need for a more stringent CLP classification for mutagenicity as opposed to the current classification as mutagen category 2 (Danish Ministry of the Environment, 2016). Additionally, n-[4-(oxiranylmethoxy) phenyl]-n-(oxiranylmethyl)-2-oxiranemethanamine (CAS number 5026-74-4), which produced positive in vitro results in multiple gene mutation tests as well as in a chromosome aberration assay, has also been selected for further investigation by the Danish authorities, although the official evaluation process has not yet started.

By consulting a limited number of well-chosen literature sources, experimental genotoxicity data could thus be obtained for most of the 106 "high priority" printed paper and board FCM substances. Although the EURL ECVAM and ECHA databases contain an important amount of additional in vitro and - to a lesser extent - in vivo genotoxicity test results, it should be kept in mind that the data included in the latter two databases have often not been subjected to a critical evaluation by an independent regulatory body. This is especially true for the test results included in the ECHA database, as these were submitted by REACH registrants. The data have been officially evaluated by a Member State only for a limited number of registered substances (Mertens et al., 2016).

Lastly, for 12 out of the 106 substances, a harmonized CLP classification for mutagenicity was established. More specifically, 10 substances are classified as mutagen category 2, whereas 2 are assigned to the mutagen category $1 \mathrm{~B}\left(\mathrm{Tab} . \mathrm{S}^{3}\right)$.

\subsection{Substance categorization}

All substances were categorized based on the genotoxicity data collected from the literature, harmonized CLP classification for mutagenicity, and inclusion (yes/no) in the training set of one or more of the in silico models (see Van Bossuyt et al., 2017) $\left(\mathrm{Tab} . \mathrm{S}^{3}\right)$.

Category 1 includes 19 substances for which in vivo genotoxicity is confirmed based on previous official evaluation in a nonFCM context (5 substances) or genotoxicity data reported in the EURL ECVAM and/or ECHA database (10 substances) or for which at least a harmonized CLP classification for mutagenicity has been established (4 substances).

Category 2 consists of 40 substances for which positive in vitro genotoxicity data have been reported in previous evaluations in a non-FCM context or the EURL ECVAM and/or ECHA database. Training set mutagens were also included in category 2 , although confirmatory literature data were not always publicly available.

In category $3 \mathrm{~A}$, the 31 substances without any genotoxicity data are listed, whereas the 9 substances with (not officially ver- ified) negative gene mutation data but without data on chromosome aberration potential are listed in category $3 \mathrm{~B}$.

Category 4 contains 4 substances considered to be non-genotoxic in vitro based on (not officially verified) genotoxicity data submitted by REACH registrants.

Category 5 includes the 3 substances for which in vivo genotoxicity has been ruled out based on an official evaluation by an EU authority.

Overall, the collected data allow determination of the in vitro and sometimes even in vivo genotoxic potential for the majority of the compounds. More data, however, are needed for nearly $38 \%$ of the substances (i.e., those in categories $3 \mathrm{~A}$ and $3 \mathrm{~B}$ ).

\subsection{In vitro gene mutation potential of the non-evaluated substances}

Since the goal of the prioritization strategy is to obtain a first indication of the gene mutation potential rather than to carry out an in-depth in vitro gene mutation study, the available substances from categories $3 \mathrm{~A}, 3 \mathrm{~B}$, and 4 were evaluated in a "shortened version" of the Ames test using 2 Salmonella typhimurium tester strains. Importantly, the majority of the substances selected for in vitro testing were not (commercially) available. The non-availability of these substances, in combination with the lack of (public) literature data, may be an indication of their limited use, although this is not guaranteed.

\subsubsection{Ames test results of the substances in category $\mathbf{3 A}$}

Twelve (out of 31) substances included in category $3 \mathrm{~A}$ were commercially available and could thus be evaluated in vitro (Tab. 4 and Fig. $\mathrm{S}^{3}$ ). Six of these substances already tested positive in the first strain, i.e., TA100, indicating that they induce base pair substitutions in genetic material (Barnes et al., 1982). When tester strain TA98 was applied, another 2 substances were identified as positive in causing frameshift mutations in the bacteria (Isono and Yourno, 1974). In addition, 2 substances with an aromatic (di)azo structure tested positive in a modified Ames test. As an example, the Ames test results for the substance 1-(methylamino)anthraquinone (CAS number 82-382 ) are graphically presented in Figure 2 . This substance tested negative in strain TA100 both in the absence and presence of S9, but positive in strain TA98 in the presence of S9. Indeed, under these conditions, a dose-dependent increase of the mean number of revertant colonies was reported that reached an induction factor (i.e., multiple of solvent control) of 2.12 for the highest test concentration of $624 \mu \mathrm{M}$.

For 2 out of the 12 substances, no induction of gene mutations was observed in neither the TA100 nor the TA98 strain under the applied test conditions. Both substances, i.e., 4-[(2,5dichlorophenyl)azo]-3-hydroxy-N-(2-methoxyphenyl)naphthalene-2-carboxamide and 9,10-diethoxyanthracene, should be further tested in the remaining strains of the standard OECD set (OECD, 1997). Interestingly, negative results from an in vitro bacterial reverse gene mutation assay on 4-[(2,5-dichlorophenyl)azo]-

\footnotetext{
3 doi:10.14573/altex.1810011s
} 
Tab. 4: Overview of Ames test results for the 12 (commercially) available substances assigned to category 3A Results are indicated as positive (+), negative (-) or not available (NA) for experiments in the absence (-S9) and presence (+S9) of an S9 metabolization system.

\begin{tabular}{|c|c|c|c|c|c|c|c|}
\hline \multirow[t]{2}{*}{ CAS number } & \multirow[t]{2}{*}{ Chemical name } & \multirow[t]{2}{*}{ Provider } & \multirow[t]{2}{*}{ Purity } & \multicolumn{2}{|c|}{ Strain TA100 } & \multicolumn{2}{|c|}{ Strain TA98 } \\
\hline & & & & $-S 9$ & $+\mathrm{S} 9$ & -S9 & $+\mathrm{S} 9$ \\
\hline $82-38-2$ & 1-(Methylamino)anthraquinone & Sigma-Aldrich & $98 \%$ & - & - & - & + \\
\hline $938-18-1$ & 2,4,6-Trimethylbenzoyl chloride & Sigma-Aldrich & $97 \%$ & + & - & NA & NA \\
\hline $1208-52-2$ & 2,4'-Methylenedianiline & Ark Pharm & $\geq 95 \%$ & - & - & - & + \\
\hline $1742-95-6$ & 4-Aminonaphthalene-1,8-dicarboximide & Sigma-Aldrich & $\begin{array}{l}\text { Not } \\
\text { specified }\end{array}$ & - & + & NA & NA \\
\hline 2095-03-6 & 2,2'-[Methylenebis(p-phenyleneoxymethylene)]bisoxirane & Sigma-Aldrich & $\geq 95 \%$ & + & + & NA & NA \\
\hline $3176-79-2$ & 1-[[3-Methyl-4-[(3-methylphenyl)azo]phenyl]azo]-2-naphthol & Sigma-Aldrich & $\geq 97 \%$ & NA & NA & NA & + \\
\hline $3454-29-3$ & $\begin{array}{l}\text { 1-(2,3-Epoxypropoxy)-2,2-bis[(2,3-epoxypropoxy)methyl] } \\
\text { butane }\end{array}$ & Sigma-Aldrich & $\begin{array}{l}\text { Not } \\
\text { specified }\end{array}$ & + & + & NA & NA \\
\hline $6410-38-4$ & $\begin{array}{l}\text { 4-[(2,5-Dichlorophenyl)azo]-3-hydroxy-N-(2-methoxyphenyl) } \\
\text { naphthalene-2-carboxamide }\end{array}$ & Confidential & $\begin{array}{l}\text { Not } \\
\text { specified }\end{array}$ & NA & NA & NA & - \\
\hline $31482-56-1$ & 3-[Ethyl[4-[(4-nitrophenyl)azo]phenyl]amino]propiononitrile & Sigma-Aldrich & $95 \%$ & NA & NA & NA & + \\
\hline $36215-07-3$ & 1-Chloro-3-methoxypropane & Sigma-Aldrich & $\geq 99 \%$ & + & - & NA & NA \\
\hline 50593-68-5 & 3-Chloro-6-nitro-1H-indazole & Ark Pharm & $97 \%$ & + & + & NA & NA \\
\hline 68818-86-0 & 9,10-Diethoxyanthracene & Ark Pharm & $97 \%$ & - & - & - & - \\
\hline
\end{tabular}

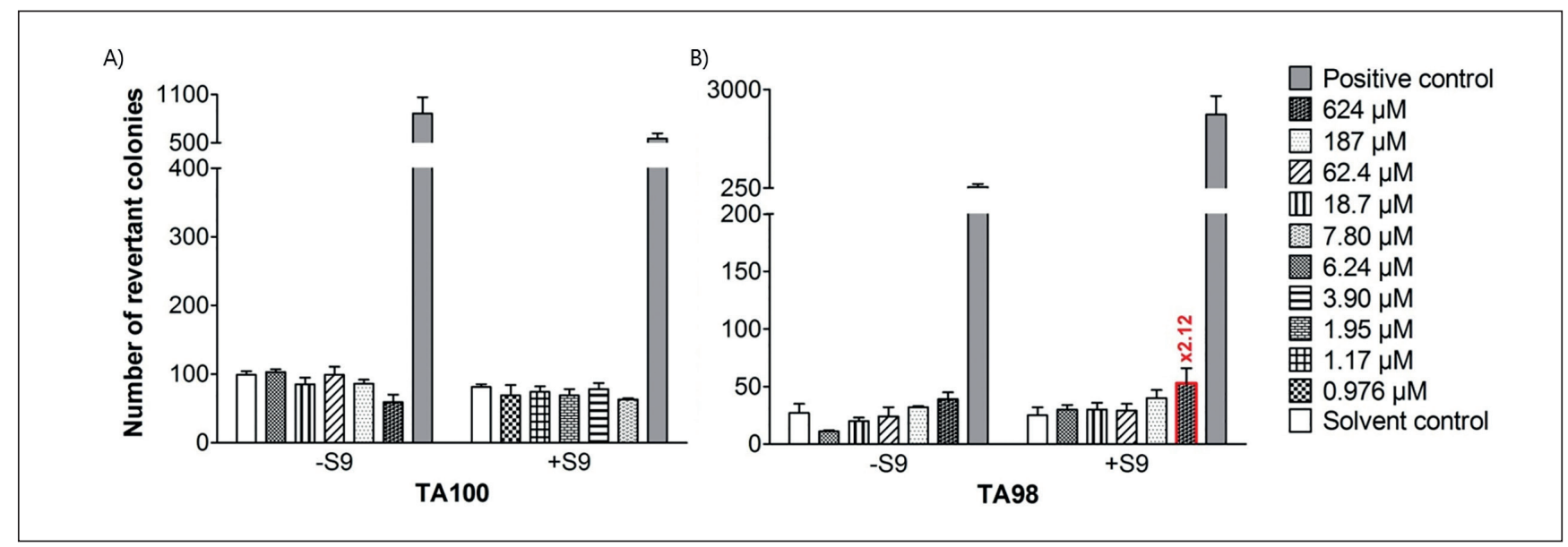

Fig. 2: Ames test results for the substance 1-(methylamino)anthraquinone

Mean and standard deviation of revertant colonies counted in triplicate plates are expressed as a function of tester strain (A, TA100; B, TA98) and metabolic condition. For a positive result, the induction factor (i.e., multiple of solvent control) is indicated in red.

3-hydroxy-N-(2-methoxyphenyl)naphthalene-2-carboxamide have recently become available through the ECHA database (ECHA, 2017a). The study concerned was assigned a Klimisch score of 1 (Klimisch et al., 1997), although an independent evaluation has not (yet) been performed. A full search for all publicly available genotoxicity data on 9,10-diethoxyanthracene did not yield information on its genotoxic potential. However, this substance is derived from 9,10-anthraquinone (Fig. 3), for which negative test results from a bacterial reverse gene mutation test, an in vitro mammalian cell gene mutation test, and an in vitro mammalian chromosome aberration assay have been submitted by ECHA registrants (all with a Klimisch score of 1) (ECHA, 2017 b). Whereas in vitro genotoxicity of 9,10-anthraquinone is doubted, the substance is of concern to ECHA (and others) based on positive findings for the carcinogenicity endpoint. Moreover, the substance is presumed to have carcinogenic potential for humans under the CLP regulation (carcinogen category 1B) (ECHA, $2017 \mathrm{~b}$ ) and is possibly carcinogenic to humans according to the International Agency for Research on Cancer (IARC) (Group 2B) (IARC, 2013). 
A<smiles>O=C1c2ccccc2C(=O)c2ccccc21</smiles>

B<smiles>CCOc1c2ccccc2c(OCC)c2ccccc12</smiles>

Fig. 3: Structural formula of A) 9,10-anthraquinone and B) 9,10-diethoxyanthracene

For substances without publicly available genotoxicity data and that are commercially available, the previously reported in silico results (Van Bossuyt et al., 2017) were thus highly predictive for the in vitro results, as more than $83 \%$ (10/12) were indeed mutagenic in the Ames test. Taking into consideration that the substances have only been tested in 2 out of the 5 standard bacterial tester strains (OECD, 1997), the predictive performance of the in silico approach may be even higher.

\subsubsection{Ames test results of the substances in categories $3 B$ and 4}

For the substances in categories $3 \mathrm{~B}$ and 4, negative Ames test results were reported by ECHA registrants, but these have not been independently reviewed. Furthermore, the current literature consultation identified 3 substances (CAS number 78-87-5, 107-07-3, and 556-52-5) for which pos- itive results were found in the EURL ECVAM database, whereas they were reported negative in the ECHA database when tested for the same genotoxic endpoint (see paragraph 3.1). Thus, the Ames test was also performed on the 7 substances of categories $3 \mathrm{~B}$ and 4 that were commercially available (Tab. 5 and Fig. $\mathrm{S}^{3}$ ), i.e., 5 substances (out of 9) of category $3 \mathrm{~B}$ and 2 substances (out of 4) of category 4. Six out of the 7 substances were characterized by at least 1 aromatic azo bond and for these only a modified test in strain TA98 in the presence of an S9 metabolization mix was performed.

Negative results were obtained for all substances except for n-(2,3-dihydro-2-oxo-1H-benzimidazol-5-yl)-3-hydroxy-4-[[2methoxy-5-[(phenylamino)carbonyl $]$ phenyl $]$ azo $]$ naphthalene2-carboxamide (CAS number 12225-06-8). This substance with an aromatic azo structure induced gene mutations in tester strain TA98 in the presence of S9 metabolization mix. The positive result may be caused by an impurity, as the purity of the test substance was not specified by the manufacturer. Importantly, however, the mutagenic effect appeared already at the lowest exposure level of $3.88 \mu \mathrm{M}$, where it was associated with a considerably high induction factor of 5.15 (Fig. S2 ${ }^{3}$ ).

As recommended, a modified test protocol (Prival et al., 1982; OECD, 1997) was used to evaluate the in vitro gene mutation potential of azo dyes. All study substances were, however, selected based on positive predictions in so-called global (i.e., general) in silico models. Poor performance of such models for azo dyes has been reported in the literature; the azo group is often identified as a mutagenic moiety (Benigni and Bossa, 2008; Ferrari and Gini, 2010) without consideration of the potential

Tab. 5: Overview of Ames test results for the seven (commercially) available substances assigned to categories $3 B$ and 4 Results are indicated as positive (+), negative (-) or not available (NA) for experiments in the absence (-S9) and presence (+S9) of an S9 metabolization system.

\begin{tabular}{|c|c|c|c|c|c|c|c|}
\hline \multirow[t]{2}{*}{ CAS number } & \multirow[t]{2}{*}{ Chemical name } & \multirow[t]{2}{*}{ Provider } & \multirow[t]{2}{*}{ Purity } & \multicolumn{2}{|c|}{ Strain TA100 } & \multicolumn{2}{|c|}{ Strain TA98 } \\
\hline & & & & $-S 9$ & + S9 & $-S 9$ & $+\mathrm{S} 9$ \\
\hline $4378-61-4$ & 4,10-Dibromodibenzo[def,mno]chrysene-6,12-dione & Ark Pharm & $\geq 95 \%$ & - & - & - & - \\
\hline $12225-06-8$ & $\begin{array}{l}\mathrm{N}-(2,3-\text { dihydro-2-oxo-1H-benzimidazol-5-yl)-3-hydroxy-4- } \\
{[[2-\text { methoxy-5-[(phenylamino)carbonyl]phenyl]azo] }} \\
\text { naphthalene-2-carboxamide }\end{array}$ & Confidential & $\begin{array}{l}\text { Not } \\
\text { specified }\end{array}$ & NA & NA & NA & + \\
\hline $36968-27-1$ & $\begin{array}{l}\text { 4-[[4-(Aminocarbonyl)phenyl]azo]-3-hydroxy-N-(2-methoxy } \\
\text { phenyl)naphthalene-2-carboxamide }\end{array}$ & Confidential & $\begin{array}{l}\text { Not } \\
\text { specified }\end{array}$ & NA & NA & NA & - \\
\hline $51920-12-8$ & $\begin{array}{l}\text { N-(2,3-dihydro-2-oxo-1H-benzimidazol-5-yl)-3-hydroxy-4- } \\
\text { [[5-methoxy-2-methyl-4-[(methylamino)sulphonyl]phenyl]azo] } \\
\text { naphthalene-2-carboxamide }\end{array}$ & Confidential & $\begin{array}{l}\text { Not } \\
\text { specified }\end{array}$ & NA & NA & NA & - \\
\hline $59487-23-9$ & $\begin{array}{l}\text { 4-[[5-[[[4-(aminocarbonyl)phenyl]amino]carbonyl]-2-methoxy } \\
\text { phenyl]azo]-N-(5-chloro-2,4-dimethoxyphenyl)-3-hydroxy } \\
\text { naphthalene-2-carboxamide }\end{array}$ & Confidential & $\begin{array}{l}\text { Not } \\
\text { specified }\end{array}$ & NA & NA & NA & - \\
\hline $61847-48-1$ & $\begin{array}{l}\text { Methyl 4-[[(2,5-dichlorophenyl)amino]carbonyl]-2- } \\
\text { [[2-hydroxy-3-[[(2-methoxyphenyl)amino] carbonyl]-1- } \\
\text { naphthyl]azo]benzoate }\end{array}$ & Confidential & $\begin{array}{l}\text { Not } \\
\text { specified }\end{array}$ & NA & NA & NA & - \\
\hline $68516-75-6$ & $\begin{array}{l}\text { N,N'-naphthalene-1,5-diylbis[4-[(2,3-dichlorophenyl)azo]-3- } \\
\text { hydroxynaphthalene-2-carboxamide] }\end{array}$ & Confidential & $\begin{array}{l}\text { Not } \\
\text { specified }\end{array}$ & NA & NA & NA & - \\
\hline
\end{tabular}


influence of other chemical features. Consequently, global in silico models are generally characterized by an unacceptably low specificity for azo dyes, producing a high number of false positives (Gadaleta et al., 2016). In this case, local (i.e., specific) in silico prediction models for azo dyes, such as the ones described by Manganelli et al. (2016), may demonstrate better performance. Interestingly, by applying the two local in silico Ames test models (Van Bossuyt et al., 2017), 89\% (8/9) of all aromatic azo dyes that have been tested in vitro were - in retrospect - correctly predicted as negative (6 substances) or positive ( 2 substances). For 1 substance, contradictory predictions had been obtained (negative in one model but positive in the other model).

\subsection{Priority ranking of the substances for further investigation}

The genotoxicity data collected from the literature and subsequent in vitro experiments permit the priority ranking of the 106 study substances for further investigation (Fig. 4). A flow chart of the complete prioritization strategy is presented in Figure 5.

Nineteen substances (18\%) are confirmed in vivo genotoxins and/or subject to harmonized CLP classification for mutagenicity, thus of very high priority for further investigation (Tab. 6). All of these substances contain well-known molecular moieties (i.e., structural alerts) responsible for the induction of genotoxicity (Ashby and Tennant, 1988; Bailey et al., 2005; Benigni 2005; Kazius et al., 2005) through covalent binding of the electrophilic substance to nucleophilic DNA components (Ashby, 1985; Miller and Miller, 1981). Except for 1 substance that serves as a solvent (i.e., 7-oxabicyclo[4.1.0]hept-3-ylmethyl 7-oxabicyclo [4.1.0] heptane-3-carboxylate), they are all used as a monomer for the manufacture of printed paper and board FCM (Van Bossuyt et al., 2017). Interestingly, monomers are reactive by nature and are purposely applied to achieve the formation of polymers. Consequently, they are not expected to be present in the finished FCM. However, they may (partly) remain if not fully utilized.

Previous results (Van Bossuyt et al., 2016) indicate that 5 of the 19 substances of very high concern not only demonstrate physicochemical properties related to high migration and bioavailability potential, but are also included in both the "Flavourings, Additives, and food Contact materials Exposure Tool" (FACET) list and ECHA's Substances of Very High Concern (SVHC) list. Inclusion in the FACET and SVHC lists implies that these substances are used in primary food packaging materials and have already been recognized to be of very high concern within the REACH framework, respectively. Four substances are of concern based on their carcinogenic potential and 1 substance due to mutagenic properties. Importantly, 1 of the carcinogenic substances, i.e., 4,4'-methylenedianiline (bis(4-aminophenyl) methane) is also included in the Authorisation List (Annex XIV) of REACH (Van Bossuyt et al., 2016). The placing on the EU market of this substance is prohibited since 21 August 2014 (ECHA, 2017c).

A large number of 51 substances (48\%) are of high priority, based on their in vitro genotoxicity (gene mutations and/or chromosome aberrations).

Almost one third of the substances (31\%) are considered of medium priority for in-depth evaluation. They include, in decreasing order of priority, the 21 substances for which insufficient in vitro genotoxicity data were retrieved for both mutagenicity endpoints, the 9 substances that are (non-officially) reported not to induce gene mutations but for which data on chromosome aberration potential are lacking, and lastly, the 3 substances that tested negative for both mutagenicity endpoints although these results have not been officially evaluated by an EU authority or Member State.

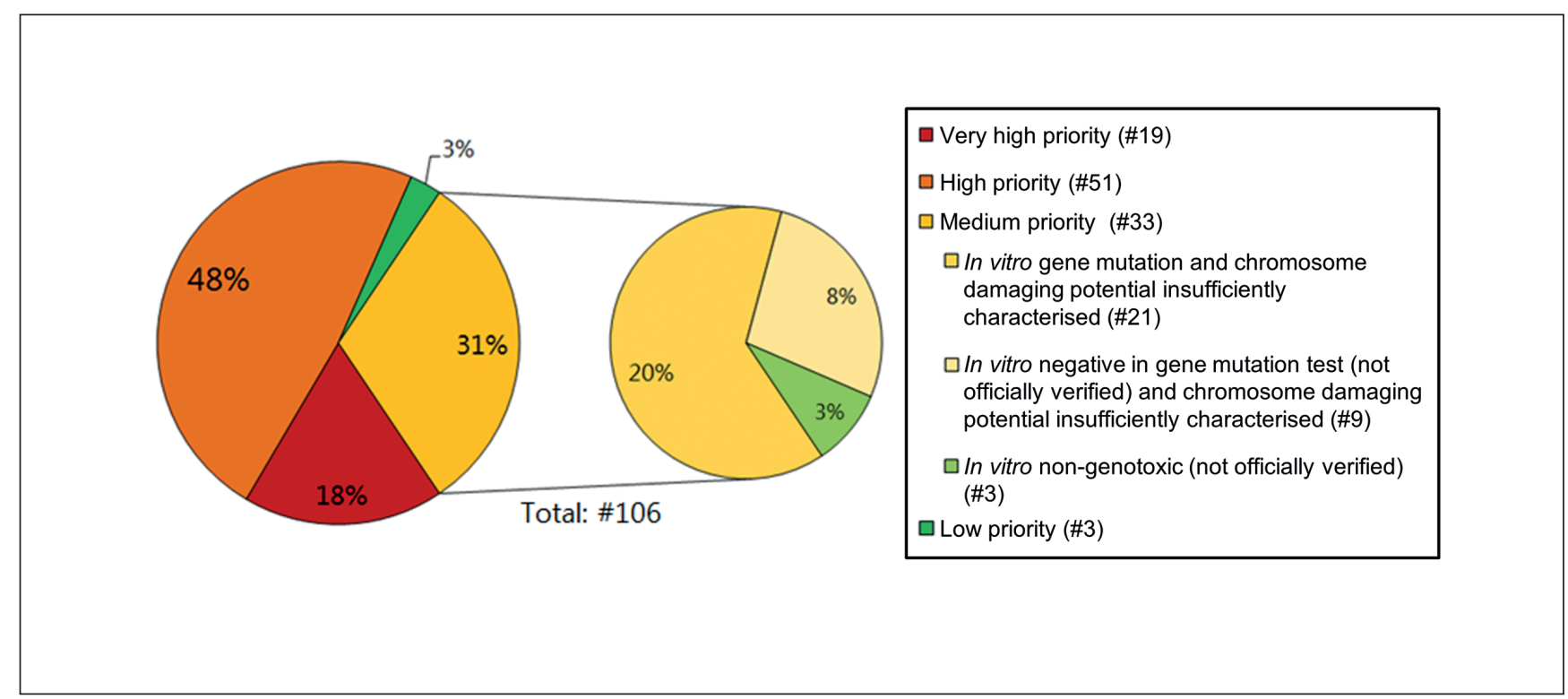

Fig. 4: Prioritization of the 106 printed paper and board FCM substances for in-depth evaluation based on their genotoxic potential 
Tab. 6: The 19 substances of very high priority for investigation of actual use and migration

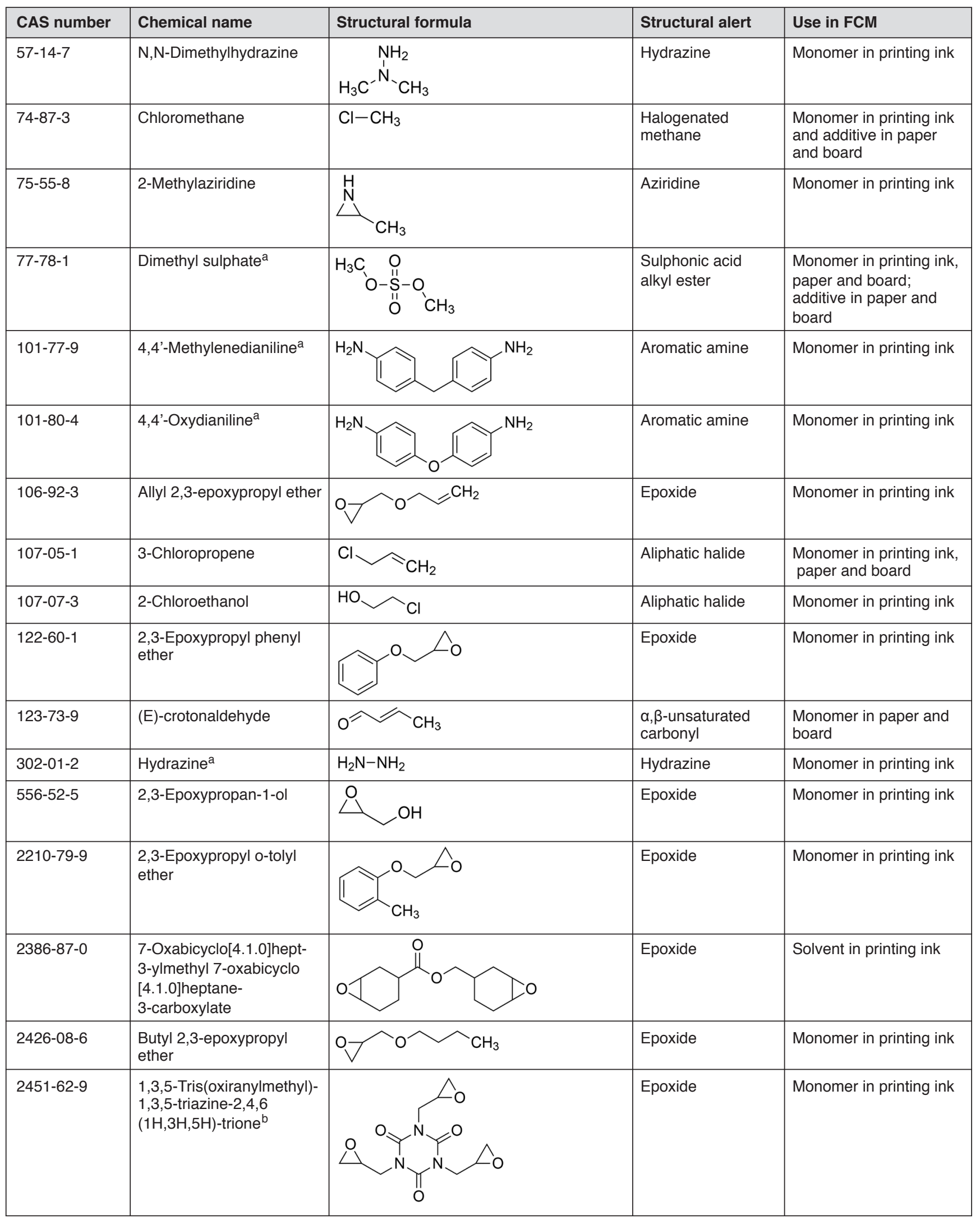




\begin{tabular}{|l|l|l|l|l|}
\hline CAS number & Chemical name & Structural formula & Structural alert & Use in FCM \\
\hline $2530-83-8$ & $\begin{array}{l}\text { [3-(2,3-Epoxypropoxy) } \\
\text { propyl]trimethoxysilane }\end{array}$ & $\begin{array}{l}\text { Monomer in printing ink; } \\
\text { additive in paper and } \\
\text { board }\end{array}$ \\
\hline $4170-30-3$ & Crotonaldehyde & O & E, 3 -unsaturated & Monomer in printing ink \\
\hline
\end{tabular}

a Substance demonstrating physicochemical properties related to high migration and bioavailability potential and included in both the FACET list and ECHA's SVHC list (based on carcinogenic potential). ${ }^{\text {b }}$ Substance demonstrating physicochemical properties related to high migration and bioavailability potential and included in both the FACET list and ECHA's SVHC list (based on mutagenic potential).

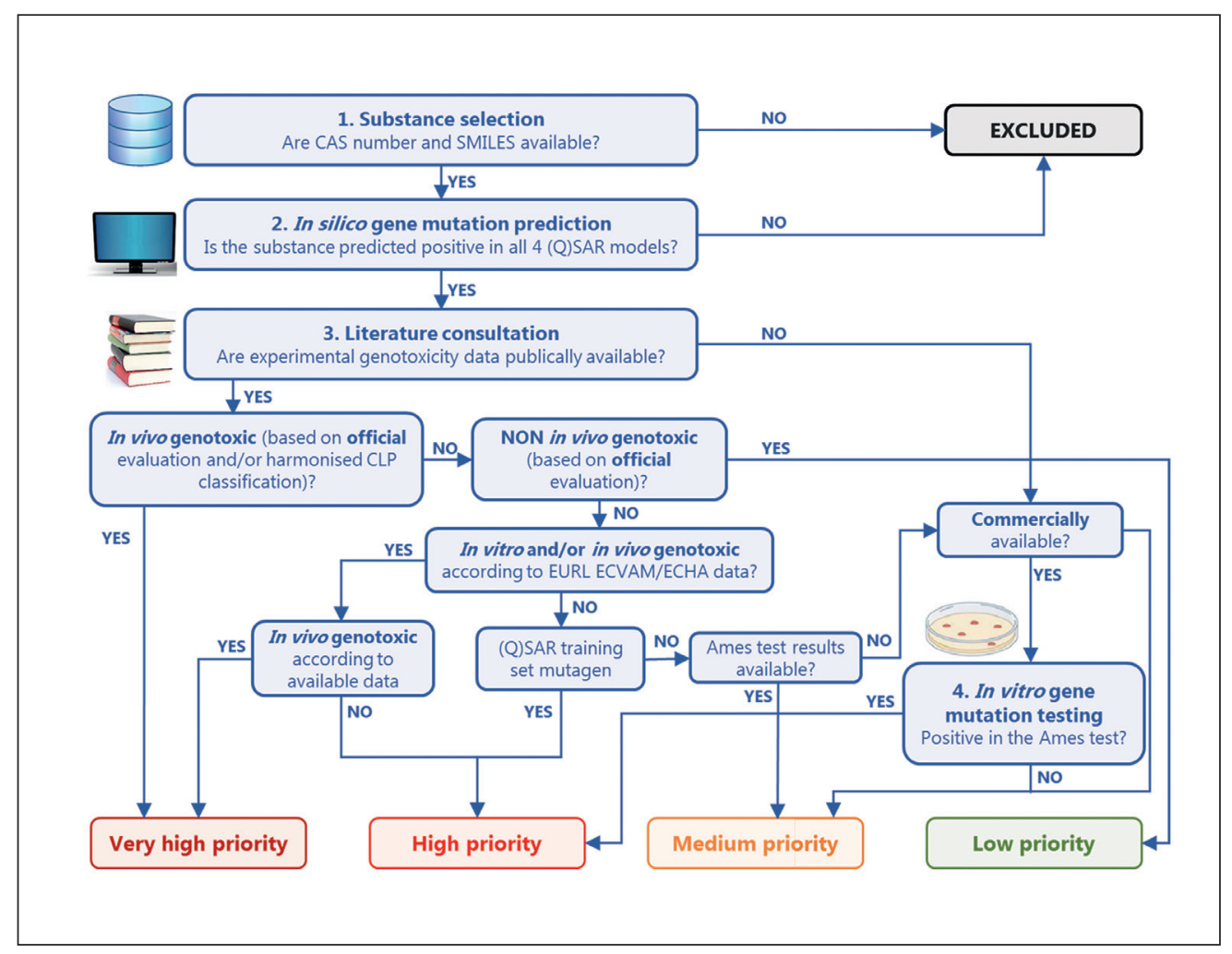

Fig. 5: Prioritization strategy flow chart

Finally, no further genotoxicity evaluation is needed for the 3 substances (3\%) that were previously considered non-genotoxic in vivo by the EU authorities in a non-FCM context and as a consequence, these are regarded of low priority.

For the majority of the substances, further genotoxicity testing is thus required to elucidate their in vivo genotoxic potential. Since this mostly (51 substances) concerns confirmed in vitro genotoxins, a relatively large number of in vivo follow-up experiments would be necessary. However, to limit animal testing as much as possible in line with the $3 \mathrm{R}$ principles (Russell and Burch, 1959; EU, 2010), a more appropriate next step would consist of collecting information on the current use in FCM and actual exposure to these substances. Unfortunately, such information is not readily available (Van Bossuyt et al., 2016). The FACET project (Hearty et al., 2011), however, demonstrated that it is possible to gather usage information on substances applied for the manufacture of primary packaging FCM without interfering with corporate confidentiality. One possibility could thus be the compilation of an updated tool that includes the substances used in all types of FCM, thus also secondary packaging and articles.

Importantly, genotoxicants are not necessarily excluded as starting products for FCM manufacture (Mertens et al., 2017). For example, under EU Regulation 10/2011, a number of geno- 
toxic substances are authorized in plastic materials and articles (EU, 2011). This is explained by the fact that some substances are highly reactive and/or volatile and consequently will not migrate into the food. Their migration should nevertheless be investigated and should not be detected even under worst case scenarios. Additionally, a restriction on the maximum amount that can be used in the FCM product is set for most of these genotoxic substances. Despite the general recommendation not to use CMR substances in the manufacture of non-harmonized FCMs, their application will thus not necessarily impact human health (Mertens et al., 2017).

\section{Conclusion}

A prioritization strategy for in-depth safety evaluation of non-evaluated printed paper and board FCM substances that were predicted positive for the induction of gene mutations in a battery of in silico models was further developed. The refined strategy consisted of supplementing publicly available genotoxicity data with in vitro gene mutation experiments whenever necessary. As such, a refined priority ranking was obtained for the 106 study substances involved. Nineteen substances of very high concern were identified based on their in vivo genotoxicity. Furthermore, 5 of these are (i) listed as a SVHC by the ECHA, (ii) demonstrate physicochemical properties linked to a high migration potential and oral bioavailability, and (iii) are used in primary food packaging materials.

The current animal-free strategy proved useful in detecting FCM substances of highest concern. Its application can therefore also be considered to prioritize other compounds of emerging concern. Moreover, considering that people are estimated to be exposed to about 100,000 relevant synthetic chemicals - in addition to likely ten thousands of naturally occurring substances - out of which only 5 to $10 \%$ have actually undergone (widely varying in depth) safety assessment (Hartung, 2017), the general value of prioritization strategies such as the one proposed here may be of significant importance.

\section{References}

Alphenaar, P. A. and van Houten, M. (2016). Emerging contam inants. http://www.emergingcontaminants.eu/

Ashby, J. (1985). Fundamental structural alerts to potential carcinogenicity or noncarcinogenicity. Environ Mutagen 7, 919921. doi:10.1002/em.2860070613

Ashby, J. and Tennant, R. W. (1988). Chemical structure, Salmonella mutagenicity and extent of carcinogenicity as indicators of genotoxic carcinogenesis among 222 chemicals tested by the U.S.NCI/NTP. Mutat Res 204, 17-115. doi:10.1016/01651218(88)90114-0

Bailey, A. B., Chanderbhan, N., Collazo-Braier, N. et al. (2005). The use of structure-activity relationship analysis in the food contact notification program. Regul Pharmacol Toxicol 42, 225-235. doi:10.1016/j.yrtph.2005.04.006

Barnes, W., Tuley, E. and Eisenstadt, E. (1982). Base-sequence analysis of His+ revertants of the hiG46 missense mutation in Salmonella typhimurium. Environ Mutagen 4, 297 (abstr. Aa-1).

Bengtström, L., Rosenmai, A. K., Trier, X. et al. (2016). Non-targeted screening for contaminants in paper and board food-contact materials using effect-directed analysis and accurate mass spectrometry. Food Addit Contam Part A Chem Anal Control Expo Risk Assess 33, 1080-1093. doi:10.1080/19440049.201 6.1184941

Benigni, R. (2005). Structure-activity relationship studies of chemical mutagens and carcinogens: Mechanistic investigations and prediction approaches. Chem Rev 105, 1767-1800. doi:10.1021/cr030049y

Benigni, R. and Bossa, C. (2008). Structure alerts for carcinogenicity, and the Salmonella assay system: A novel insight through the chemical relational database technology. Mutat Res 659, 248-261. doi:10.1016/j.mrrev.2008.05.003

Borchers, A., Teuber, S. S., Keen, C. L. and Gershwin, M. E. (2010). Food safety. Clin Rev Allergy Immunol 39, 95-141. doi:10.1007/s12016-009-8176-4

Claudio, L. (2012). Our food: Packaging \& public health. Environ Health Perspect 120, A232-A237. doi:10.1289/ehp.120-a232

Danish Ministry of the Environment (2016). Justification document for the selection of a CoRAP substance: 2,3-epoxypropyl o-tolylether.https://echa.europa.eu/information-on-chemicals/ evaluation/community-rolling-action-plan/corap-table/-/ dislist/details/0b0236e180b882c5

ECHA (2017a). 4-[(2,5-dichlorophenyl)azo]-3-hydroxy-N-(2methoxyphenyl)naphthalene-2-carboxamide. Genetic toxicity: In vitro. https:/echa.europa.eu/nl/registration-dossier/-/ registered-dossier/21751/7/7/2

ECHA (2017b). Anthraquinone. Genetic toxicity: In vitro. https://echa.europa.eu/nl/registration-dossier/-/registereddossier $/ 2211 / 7 / 7 / 2 /$ ? documentUUID=bf6ff0 $6 \mathrm{a}-4 \mathrm{fe} 8$ 467d-9ede-acc3999b31bc

ECHA (2017c). Authorisation list. 4,4'-methylenedianiline. https://echa.europa.eu/nl/authorisation-list/-/dislist/details/ 0b0236e1807df8e3

EFSA (2012). Report of ESCO WG on Non-plastic Food Contact Materials. EFSA Supporting Publications 8: 139E. doi:10.2903/sp.efsa.2011.EN-139

EU - European Union (1993). Council Regulation (EEC) No 793/93 of 23 March 1993 on the evaluation and control of therisks of existing substances. OJ L 84, 1-75. https://eur-lex.europa. eu/legal-content/EN/TXT/?uri=CELEX\%3A31993R0793

EU (2004). Regulation (EC) No 1935/2004 of the European Parliament and of the Council of 27 October 2004 on materials and articles intended to come into contact with food and repealing Directives 80/590/EEC and 89/109/EEC. OJ L 338, 4-17. https://eur-lex.europa.eu/legal-content/en/ALL/?uri=CELEX$\% 3 A 32004 R 1935$

EU (2006). Regulation (EC) No 1907/2006 of the European Parliament and of the Council of 18 December 2006 concerning the registration, evaluation, authorisation and restriction of chemicals (REACH). OJ L 396, 1-849. https:// eur-lex.europa.eu/legal-content/EN/TXT/?uri=CELEX\%3A02006R1907-20140410 
EU (2008). Regulation (EC) No 1272/2008 of the European Parliament and of the Council of 16 December 2008 on classification, labelling and packaging of substances and mixtures, amending and repealing Directives 67/548/EEC and 1999/45/ EC, and amending Regulation (EC) No 1907/2006. OJ L 353, 1-1355. https://eur-lex.europa.eu/legal-content/EN/TXT/?uri= CELEX\%3A32008R 1272

EU (2010). Directive 2010/63/EU of the European Parliament and of the Council of 22 September 2010 on the protection of animals used for scientific purposes. OJ L 276, 33-79. https://eur-lex.europa.eu/legal-content/EN/TXT/?uri=celex\%3A32010L0063

EU (2011). Regulation (EC) No 10/2011 of 14 January 2011 on plastic materials and articles intended to come into contact with food. OJ L 12, 1-89. https://eur-lex.europa.eu/legal-content/ $\mathrm{EN} / \mathrm{ALL} /$ ?uri=celex\%3A32011R0010

EU (2012). Regulation (EU) No 528/2012 of the European Parliament and of the Council of 22 May 2012 concerning the making available on the market and use of biocidal products. OJ L 167, 1-123. https://eur-lex.europa.eu/legal-content/EN/ TXT/?uri=celex\%3A32012R0528

EU (2016). Food Contact Materials - How to Ensure Food Safety and Technological Innovation in the Future? Workshop Proceedings. 53BIP/A/ENVI/2015-20. http://www.europarl. europa.eu/RegData/etudes/STUD/2016/578967/IPOL_ STU(2016)578967_EN.pdf

EU (2017a). Chemicals and the circular economy: Dealing with substances of concern (Briefing). European Parliamentary Research Service. PE 608.725. https:/www.europarl. europa.eu/thinktank/en/document.html?reference=EPRS BRI(2017)608725

EU (2017b). EURL ECVAM Genotoxicity and Carcinogenicity Consolidated Database of Ames Positive Chemicals. https:// eurl-ecvam.jrc.ec.europa.eu/databases/genotoxicity-carcinogenicity-db

European Parliamentary Research Service (2016). Food Contact Materials - Regulation (EC) 1935/2004: European Implementation Assessment. doi:10.2861/162638

Ferrari, T. and Gini, G. (2010). An open source multistep model to predict mutagenicity from statistical analysis and relevant structural alerts. Chem Cent J 4, Suppl 1, S2. doi:10.2903/ sp.efsa.2011.EN-139

Gadaleta, D., Manganelli, S., Manganaro, A. et al. (2016). A knowledge-based expert rule system for predicting mutagenicity (Ames test) of aromatic amines and azo compounds. Toxicology 370, 20-30. doi:10.1016/j.tox.2016.09.008

Geueke, B., Wagner, C. C. and Muncke, J. (2014). Food contact substances and chemicals of concern: A comparison of inventories. Food Addit Contam Part A Chem Anal Control Expo Risk Assess 31, 1438-1450. doi:10.1080/19440049.2014.931 600

Grob, K., Biedermann, M., Scherbaum, E. et al. (2006). Food contamination with organic materials in perspective: Packaging materials as the largest and least controlled source? A view focusing on the European situation. Crit Rev Food Sci Nutr 46, 529-535. doi:10.1080/10408390500295490
Hartung, T. (2017). Evolution of toxicological science: The need for change. Int J Risk Assess Manag 20, 21-45. doi:10.1504/ IJRAM.2017.082570

Hearty, A., Gibney, M. J., Vin, K. et al. (2011). The FACET project: A chemical exposure surveillance system for Europe. Food Sci Technol 25, 26-29.

IARC - International Agency for Research on Cancer (2013). Anthraquinone. IARC Monographs 101, 41-70. http://www. monographs.iarc.fr/wp-content/uploads/2018/06/mono101001.pdf

Isono, K. and Yourno, J. (1974). Chemical carcinogens as frameshift mutagens: Salmonella DNA sequence sensitive to mutagenesis by polycyclic carcinogens. Proc Natl Acad Sci U S A 71, 1612-1617. doi:10.1073/pnas.71.5.1612

Kazius, J., McGuire, R. and Bursi, R. (2005). Derivation and validation of toxicophores for mutagenicity prediction. $J$ Med Chem 48, 312-320. doi:10.1021/jm040835a

Kirkland, D., Zeiger, E., Madia, F. and Corvi, R. (2014). Can in vitro mammalian cell genotoxicity test results be used to complement positive results in the Ames test and help predict carcinogenic or in vivo genotoxic activity? II. Construction and analysis of a consolidated database. Mutat Res Genet Toxicol Environ Mutagen 775-776, 69-80. doi:10.1016/j.mrgentox.2014.10.006

Klimisch, H. J., Andreae, M. and Tillmann, U. (1997). A systematic approach for evaluating the quality of experimental toxicological and ecotoxicological data. Regul Toxicol Pharmacol 25, 1-5. doi:10.1006/rtph.1996.1076

Manganelli, S., Benfenati, E., Manganaro, A. et al. (2016). New quantitative structure-activity relationship models improve predictability of Ames mutagenicity for aromatic azo compounds. Toxicol Sci 153, 316-326. doi:10.1093/toxsci/kfw125

Mertens, B., Simon, C., Van Bossuyt, M. et al. (2016). Investigation of the genotoxicity of substances migrating from polycarbonate replacement baby bottles to identify chemicals of high concern. Food Chem Toxicol 89, 126-137. doi:10.1016/j. fct.2016.01.009

Mertens, B., Van Bossuyt, M., Fraselle, S. et al. (2017). Coatings in food contact materials: Potential source of genotoxic contaminants? Food Chem Toxicol 106, 496-505. doi:10.1016/j. fct.2017.05.071

Miller, E. and Miller, J. (1981). Searches for ultimate chemical carcinogens and their reactions with cellular macromolecules. Cancer 47, 2327-2345. doi:10.1002/1097-0142(19810515)47: $10<2327:: A I D-C N C R 2820471003>3.0 . C O ; 2-Z$

Mortelmans, K. and Zeiger, E. (2000). The Ames Salmonella/microsome mutagenicity assay. Mut Res 455, 29-60. doi:10.1016/S0027-5107(00)00064-6

Muncke, J. (2011). Endocrine disrupting chemicals and other substances of concern in food contact materials: An updated review of exposure, effect and risk assessment. J Steroid Biochem Mol Biol 127, 118-127. doi:10.1016/j.jsbmb.2010. 10.004

Muncke, J., Myers, J. P., Scheringer, M. and Porta, M. (2014). Food packaging and migration of food contact materials: Will epidemiologists rise to the neotoxic challenge? $J$ 
Epidemiol Community Health 68, 592-594. doi:10.1136/ jech-2013-202593

OECD - Organisation for Economic Co-operation and Development (1997). OECD Guideline for Testing of Chemicals, Test No. 471: Bacterial Reverse Mutation Test. OECD Publishing, Paris, France. doi:10.1787/9789264071247-en

OECD (2000). Guidance Document on the Recognition, Assessment, and use of Clinical Signs as Humane Endpoints for Experimental Animals Used in Safety Evaluations. ENV/JM/MONO(2000)7. OECD Publishing, Paris, France. doi:10.1787/9789264078376-en

OECD (2017). The Global Portal to Information on Chemical Substances. https://www.echemportal.org

Prival, M. J. and Mitchell, V. D. (1982). Analysis of a method for testing azo dyes for mutagenic activity in Salmonella typhimurium in the presence of flavin mononucleotide and hamster liver S9. Mutat Res 97, 103-16. doi:10.1016/01651161(82)90008-5

Prival, M. J., Bell, S. J., Mitchell, V. D. et al. (1984). Mutagenicity of benzidine and benzidine-congener dyes and selected monoazo dyes in a modified Salmonella assay. Mutat Res 136, 33-47. doi:10.1016/0165-1218(84)90132-0

Rosenmai, A. K., Bengtström, L., Taxvig, C. et al. (2017). An effect-directed strategy for characterizing emerging chemicals in food contact materials made from paper and board. Food Chem Toxicol 106, 250-259. doi:10.1016/j.fct.2017.05.061

Russell, W. M. S. and Burch, R. L. (eds.) (1959). The Principles of Humane Experimental Technique. London, UK: Methuen \&
Co. Ltd. https://www.altweb.jhsph.edu/pubs/books/humane exp/het-toc

Sauvé, S. and Desrosiers, M. (2014). Areview of what is an emerging contaminant. Chem Cent J 8, 15. doi:10.1186/1752-153X$8-15$

Van Bossuyt, M., Van Hoeck, E., Vanhaecke, T. et al. (2016). Printed paper and board food contact materials as a potential source of food contamination. Regul Tox Pharm 81, 10-19. doi:10.1016/j.yrtph.2016.06.025

Van Bossuyt, M., Van Hoeck, E., Raitano, G. et al. (2017). (Q) SAR tools for priority setting: A case study with printed paper and board food contact material substances. Food Chem Toxicol 102, 109-119. doi:10.1016/j.fct.2017.02.002

Zeiger, E., Risko, K. J. and Margolin, B. H. (1985). Strategies to reduce the cost of mutagenicity screening using the Salmonella/ microsome assay. Environ Mutagen 7, 901-911. doi:10.1002/ em.2860070611

\section{Conflict of interest}

The authors declare that they have no conflicts of interest.

\section{Acknowledgements}

The authors thank Mr Roel Anthonissen and Mrs Jolien Van De Maele for their excellent technical assistance. They furthermore acknowledge Sciensano for providing financial support. 